\title{
PEMBELAJARAN EKONOMI BERJATIDIRI BANGSA
}

\author{
Rahmatullah \\ Pendidikan Ekonomi, Universitas Negeri Makassar \\ Email: rahmatullah@unm.ac.id
}

\begin{abstract}
This paper is the result of research that aims to internalize the economic values of the nation in accordance with the economic basis of the nation, namely Pancasila and Article 33 of the 1945 Constitution. This is important to be realized in order to realize the generation of the nation that has the understanding, attitude and economic behavior in accordance with economic principles of the nation. The method used refers to the Dick \& Carey model, and the product trial is done by Class Action Research approach. The results showed that the learning of the nation's national identity is very effective in applied in the learning process although it is a supplement
\end{abstract}

Keywords: Economic Learning; National Nation's Identity; Economic Behavior

\begin{abstract}
Abstrak: Tulisan ini merupakan hasil penelitian yang bertujuan untuk menginternalisasikan nilai-nilai ekonomi bangsa yang sesuai dengan dasar ekonomi bangsa yaitu pancasila dan pasal 33 UUD 1945. Hal ini penting dilakukan agar terwujud generasi bangsa yang memiliki pemahaman, sikap, dan prilaku ekonomi yang sesuai dengan prinsip-prinsip ekonomi bangsa. Metode yang digunakan mengacu pada model Dick \& Carey, dan uji coba produk dilakukan dengan pendekatan Penelitian Tindakan Kelas. Hasil penelitian menunjukkan bahwa pembelajaran ekonomi berjatidiri bangsa sangat efektif di terapkan dalam proses pembelajaran walaupun bersifat sebagai suplemen.
\end{abstract}

Kata Kunci: Pembelajaran Ekonomi; Jatidiri Ekonomi Bangsa; Perilaku Ekonomi

\section{PENDAHULUAN}

Aktifitas atau perilaku ekonomi yang dilakukan manusia merupakan cerminan dari pengetahuan dan pemahaman berekonomi yang telah diperoleh melalui proses pembelajaran, khususnya pembelajaran ekonomi pada lembaga pendidikan formal. Disadari atau tidak, materi pembelajaran ekonomi yang berlangsung pada lembaga pendidikan formal baik dari kajian teoritis maupun praktis, telah mengalami pergeseran nilai yaitu dari nilai atau prinsip yang sesuai dengan jari diri bangsa Indonesia kearah pengajaran prinsip ekonomi kapitalis (klasik dan neoklasik) sebagai yang utama.

Idealnya, materi pembelajaran ekonomi pada lembaga pendidikan formal dilakukan sebagai upaya untuk memberikan pengetahuan dan pemahaman tentang prinsip dan nilai-nilai berekonomi yang sesuai dengan jati diri bangsa,

sehingga siswa sebagai generasi bangsa dapat berperilaku yang rasional dan bertanggung jawab dalam melakukan aktifitas ekonominya. Prinsip dan nilai-nilai ekonomi yang perlu diajarkan dalam pembelajaran ekonomi bersumber dari nilai-nilai luhur bangsa sebagaimana yang diamanahkan dalam Pancasila dan pasal 33 UUD 1945 sebagai dasar perekonomian Indonesia.

Namun pada kenyataannya, materi pembelajaran ekonomi yang diajarkan lebih didominasi oleh pengetahuan yang merupakan prinsip-prinsip ekonomi kapitalis, yang berpijak pada keyakinan bahwa manusia sebagai homo economicus, yang selalu mengejar self interest secara efisien. Efisiensi ekonomi dianggap hanya terwujud melalui maksimisasi profit (profit oriented), dan minimisasi biaya. Efisensi dipercaya hanya dapat dicapai melalui persaingan pasar, sehingga pemahaman yang ditonjolkan dalam berekonomi adalah persaingan bukan kerja sama (cooperative). Implikasi dari pemahamantersebut, yaitu akan terlahir sumber daya manusia yang cenderung bersifat eksploitatif dalam berperilaku ekonomi, terutama terkait dengan pengelolaan sumber daya alam sebagai sarana untuk memenuhi kebutuhan hidup manusia. 
Selain itu, literatur pembelajaran ekonomi yang banyak tersedia lebih di dominasi oleh pemikiran kapitalis yang mencakup contohcontoh kehidupan ekonomi klasik dan neoklasik yang lebih cocok untuk negara-negara yang menganut faham kapitalis. Jika hal ini terus menerus diajarkan pada lembaga pendidikan formal di Indonesia maka sama halnya jika kita mencetak generasi yang merupakan perpanjangan tangan para kapitalis. Oleh karena itu, perlu dilakukan identifikasi nilai nilai ekonomi berjatidiri bangsa untuk kemudian diwujudkan dalam bentuk rumusan materi pembelajaran pada mata kuliah pengantar ilmu ekonomi, sehingga dapat terwujud generasi yang memiliki karakter, pola pikir, pola sikap, dan pola tindak yang sesuai dengan norma dan nilai yang mencerminkan ciri ke Indonesiaannya.

Pembelajaran ekonomi yang selama ini berlangsung pada lembaga pendidikan formal khususnya diperguruan tinggi, lebih didominasi oleh pemikiran ekonomi yang bersumber dari pemikir-pemikir ekonomi liberal dan sangat sedikit mengajarkan materi ekonomi yang sesuai dengan karakter yang sesuai dengan jati diri bangsa. Ketersediaan literatur ekonomi yang meletakkan nilai-nilai ekonomi bangsa sebagai kajian mendasar masih sedikit dibandingkan dengan literatur ekonomi hasil pemikiran ekonom liberal atau kapitalis. Hal ini sebagaimana di sebutkan oleh Suyono (2012), bahwa materi pembelajaran ekonomi disemua jenjang pendidikan sangat didominasi oleh teoriteori dan praktik-praktik kegiatan ekonomi yang berdasarkan pada pemikiran liberalis/kapitalis dan ekonomi pasar, dan sangat sedikit yang membahas tentang ekonomi Pancasila sebagai jati diri perekonomian Indonesia.

Menempatkan ekonomi Pancasila sebagai sumber nilai, moral dan etika dalam aktifitas perekonomian, berarti mengembalikan ilmu ekonomi sebagai ilmu sosial yang berketuhanan, beretika dan bermoral serta punya ciri lokalitas. Hal ini sebagaimana dikemukan oleh Mubyarto (2003) bahwa sistem ekonomi Pancasila mencakup "aturan main" kehidupan ekonomi atau hubungan-hubungan ekonomi antar pelaku-pelaku ekonomi yang didasarkan pada etika atau moral Pancasila dengan tujuan akhir mewujudkan keadilan sosial bagi seluruh rakyat Indonesia.

Dengan demikian, sumber daya manusia yang berkualitas akan lahir dari manusia yang berkarakter religius, percaya diri, dan memiliki etos kerja yang tinggi (Poespowardojo dan Hardjatno, 2010). Sumber daya manusia inilah yang akan menjalankan penyelenggaraan negara maupun sebagai pelaku pembangunan, yang lebih berorientasi kepada kesejahteraan dalam rangka peningkatan harkat dan martabat bangsa (Nugroho, 2010). Dengan demikian pendidikan yang diselenggarakan khususnya pendidikan ekonomi harus mampu menginternalisasikan nilai nilai yang sesuai dengan jati diri ekonomi bangsa yaitu Pancasila dan UUD 1945 pasal 33. Adapun nilai nilai tersebut antara lain religius, keadilan, kekeluargaan, kebersamaan, tanggung jawab, gotong royong, kemandirian, kepedulian sosial, dan cinta tanah.

\section{METODE}

Penelitian ini bertujuan untuk mengidentifikasi dan merumuskan materi pembelajaran pengantar ilmu ekonomi berjatidiri bangsa, yang mengacu pada pendekatan sistem menurut Dick dan Carey (2001). Acuan tersebut didasari oleh beberapa alasan sebagai berikut: (a) model ini mempunyai langkah-langkah yang sistematik dan cocok untuk pengembangan disain pembelajaran, (b) komponen yang dikembangkan bersifat prosedural dan saling terkait serta paling umum digunakan dan menjadi rujukan beberapa disain pengembangan pembelajaran, (d) relatif lebih sederhana namun tahapan dan komponen yang dikembangkan lebih rinci mulai dari tahap awal sampai pada tahap produk akhir.

Kegiatan uji coba dalam proses belajar
mengajar menggunakan prinsip desain
Penelitian Tindakan Kelas (PTK), yang merujuk
pada PTK model kemmis dan Taggart sebagai
dalam Sanjaya (2009), sebagai berikut:

Kegiatan uji coba dalam proses belajar mengajar menggunakan prinsip desain Penelitian Tindakan Kelas (PTK), yang merujuk dalam Sanjaya (2009), sebagai berikut: 


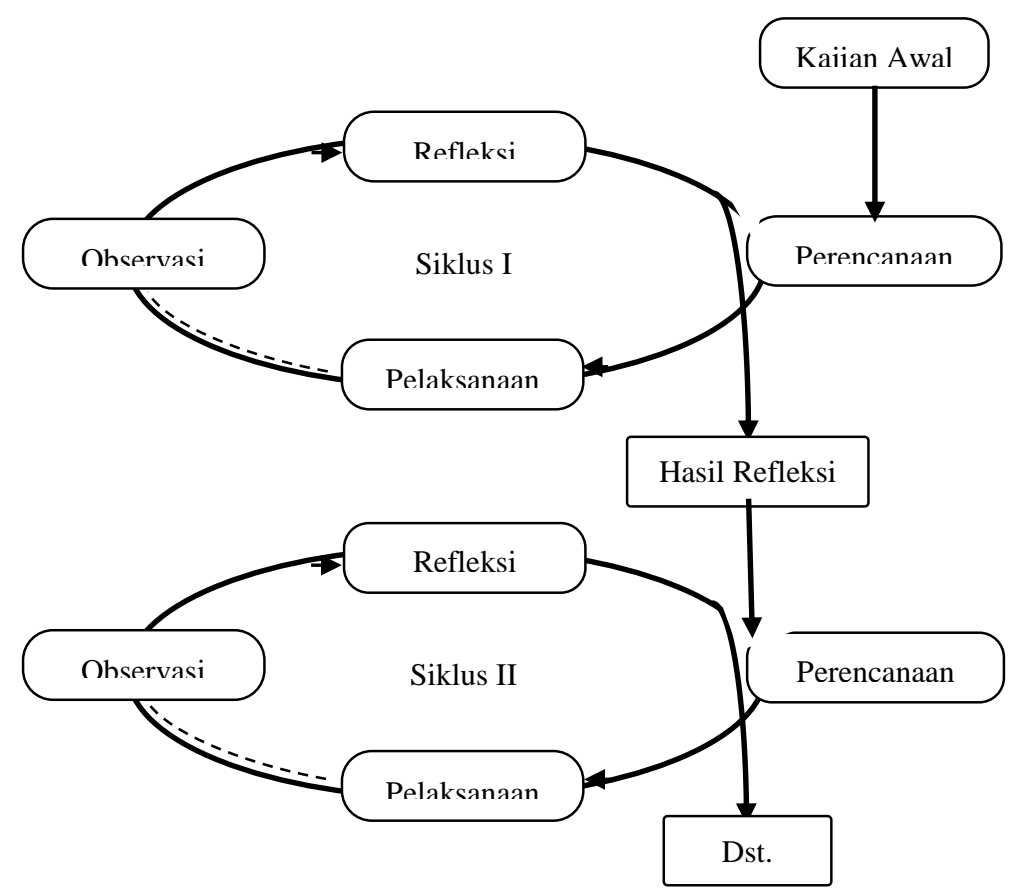

Gambar 3.1. Desain Uji Coba Lapangan dengan Model PTK

Keterangan:

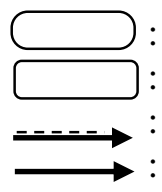

\section{: Kegiatan}

Hasil kegiatan

Kegiatan yang dilakukan bersamaan

Urutan pelaksanaan kegiatan

Analisis data yang digunakan untuk menginterpretasikan hasil penelitian ini yaitu analisis isi dan uji hasil tes Siswa. Analisis ini digunakan untuk mengolah seluruh informasi atau data penelitian yang bersifat kualitatif. Informasi atau data tersebut diperoleh sejak awal sampai akhir pelaksanaan penelitian, berupa masukan, tanggapan, kritik maupun saran perbaikan berdasarkan indikator yang telah ditentukan. Uji hasil tes siswa bertujuan untuk mengukur keberhasilan dari proses pembelajaran dan untuk mengukur keaktifan siswa selama proses pembelajaran berlangsung yang dituangkan dalam lembar observasi.

\section{HASIL DAN PEMBAHASAN}

Secara mendasar terdapat tiga karakter penting yang dapat dikembangkan untuk berlangsungnya pembelajaran ekonomi yang sesuai dengan jati diri bangsa, untuk diimplementasikan pada lembaga pendidikan formal pada semua jenjang pendidikan. Ketiga karakter tersebut menurut Wahjoedi (2015) sebagai berikut:

1. Karakter ekonomi Pancasila.
Karakter ekonomi Pancasila merupakan pesan konstitusi UUD 1945, yang berupa nilai-nilai luhur Pancasila dapat dikenalkan kepada anak didik dan mewarnai di dalam proses pembelajaran pendidikan ekonomi di lembaga pendidikan formal. Nilai-nilai luhur tersebut diantaranya berupa prinsip-prinsip ekonomi seperti: Kekeluargaan, kebersamaan, bekerjasama, kegotong royongan, mengutamakan kepentingan bersama diatas kepentingan individu, dan berpihak pada kepentingan rakyat banyak. Nilai-nilai tersebut seharusnya dipelajari secara teori dan implementatif di dalam pembelajaran pendidikan ekonomi.

2. Karakter ekonomi ekologis

Karakter ekonomi ekologi yang di dalam implementasinya telah dikenal dengan berbagai terminology, seperti ekonomi hijau (green economics), ekonomi berwawasan lingkungan (environmental economics), dan pembangunan ekonomi berkelanjutan (sustainable economics development). Pada dasarnya ekonomi ekologis memberikan pesan tentang nilai-nilai lingkungan yang harus mewarnai segala tindakan ekonomi baik produksi, konsumsi, maupun distribusi. 
Perilaku ekonomi kita diarahkan untuk menghormati dan menjaga keseimbangan alam dan lingkungan, kembali ke alam jangan merusak alam.

3. Karakter ekonomi pasar yang diadaptasi/dikendalikan.

Karakter ekonomi pasar yang diadaptasi/dikendalikan harus dapat diwujudkan dalam perekonomian Indonesia. Hal ini karena apabila sistem ekonomi pasar yang terus berjalan maka hanya akan menguntungkan fihak-fihak yang kuat yakni konsumen dan produsen yang kuat. Sementara produsen dan konsumen lemah yang merupakan mayoritas masyarakat Indonesia akan terpinggirkan. Pesan-pesan keberpihakan pada nilai-nilai ekonomi pasar terkendali harus masuk di dalam pembelajaran pendidikan ekonomi.

Dari hasil pengembangan yang dilakukan, maka diperoleh hasil sebagai berikut:

A. Rumusan Materi Ekonomi Berjatidiri Bangsa .

\begin{tabular}{|c|c|c|c|}
\hline $\begin{array}{c}\text { Standar } \\
\text { Konpetensi }\end{array}$ & $\begin{array}{l}\text { Kompetensi } \\
\text { Dasar }\end{array}$ & Materi & $\begin{array}{c}\text { Nilai-nilai } \\
\text { Fundamental } \\
\text { Ekonomi }\end{array}$ \\
\hline $\begin{array}{l}\text { Memahami } \\
\text { konsep dasar } \\
\text { Ekonomi }\end{array}$ & $\begin{array}{l}\text { Menjelaskan } \\
\text { pengertian dan } \\
\text { ruang lingkup ilmu } \\
\text { ekonomi }\end{array}$ & $\begin{array}{ll}\text { - } & \text { Pengertian ilmu } \\
& \text { ekonomi, } \\
\text { - } & \text { Ruang lingkup ilmu } \\
& \text { ekonomi, } \\
\text { - } & \text { Metode ilmu ekonomi. } \\
\text { - } & \text { Kebutuhan dan } \\
& \text { keinginan manusia, } \\
\text { - } & \text { Kelangkaan dan pilihan, } \\
\text { - } & \text { Kebutuhan manusia Vs } \\
& \text { ketersediaan sumber } \\
& \text { daya. }\end{array}$ & $\begin{array}{l}\text { - Rasa syukur } \\
\text { - Tidak memaksakan } \\
\text { kehendak } \\
\text { - Bertanggung jawab }\end{array}$ \\
\hline $\begin{array}{l}\text { Memahami Nilai- } \\
\text { nilai Dasar } \\
\text { Ekonomi } \\
\text { Pancasila }\end{array}$ & 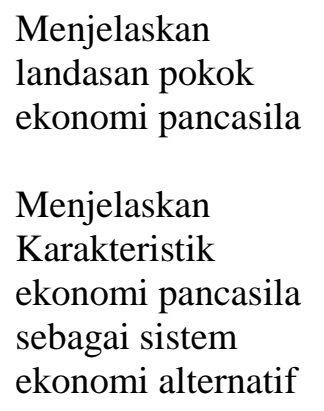 & $\begin{array}{ll}\text { - } & \text { Pengertian Ekonomi } \\
\text { Pancasila, } \\
\text { - } \\
\text { Landasan pokok } \\
\text { ekonomi pancasila. } \\
\text { - } \quad \text { Karakteristik ekonomi } \\
\text { pancasila, } \\
\text { - } \quad \text { Perbedaan antara } \\
\text { ekonomi pancasila dan } \\
\text { sistem ekonomi lainnya }\end{array}$ & $\begin{array}{ll}\text { - } & \text { Kekeluargaan } \\
\text { - } & \text { Gotong royong } \\
\text { - } & \text { Kepedulian sosial }\end{array}$ \\
\hline $\begin{array}{l}\text { Penerapan } \\
\text { Ekonomi } \\
\text { pancasila di } \\
\text { Indonesia }\end{array}$ & $\begin{array}{l}\text { Perilaku ekonomi } \\
\text { manusia berjatidiri } \\
\text { bangsa }\end{array}$ & $\begin{array}{ll}\text { - } & \text { Ekonomi Kerakyatan di } \\
\text { Indonesia } \\
\text { - } & \text { Ekonomi Kreatif di } \\
& \text { Indonesia } \\
\end{array}$ & $\begin{array}{ll}- & \text { Kemandirian } \\
- & \text { Kebersamaan } \\
\text { - } & \text { Cinta tanah air }\end{array}$ \\
\hline
\end{tabular}

Sumber: Dikembangkan Oleh Peneliti, 2017

B. Makna dan arti Pasal 33 Undang-Undang Dasar 1945 dalam kehidupan ekonomi.

1. Pasal 33 UUD 1945 ayat (1) menyatakan bahwa "Perekonomian disusun sebagai usaha bersama berdasar atas asas kekeluargaan". Usaha bersama adalah mutualism dan asas kekeluargaan adalah brotherhood. Itulah sebabnya dalam faham kolektivisme/ komunitarianisme yang berdasar mutualism dan brotherhood ini, kepentingan masyarakat (societalinteres) ditempatkan sebagai yang utama. Perekonomian disusun artinya tidak dibiarkan tersusun sendiri secara bebas (diatur oleh pasar). Susunan yang dimaksudkan adalah usaha bersama (mutualisme yang menunjukkan perbedaannya dari usaha swasta yang 
didorong oleh self interest). Asas kekeluargaan (brotherhood) menunjukkan adanya tanggungiawab bersama untuk menjamin kepentingan, kemajuan dan kemakmuran bersama.

2. Pasal 33 UUD 1945, ayat (2) menyatakan bahwa "Cabang-cabang produksi yang penting bagi negara dan yang mengusai hajat hidup orang banyak dikuasai oleh negara". Berdasarkan interpretasi historis, maka perekonomian berdasar atas demokrasi ekonomi, kemakmuran bagi semua orang. Sebab itu cabang produksi yang penting bagi negara dan yang menguasai hajat hidup orang banyak harus dikuasai oleh Negara. Kalau tidak, tampuk produksi jatuh ketangan orang-seorang yang berkuasa dan rakyat banyak yang ditindas. Hanya perusahaan yang tidak menguasai hajat hidup orang banyak boleh di tangan orang-seorang. "Penting bagi negara" maksudnya adalah cabangcabang produksi strategis, sedangkan "dikuasai" diinterpretasi bahwa dikuasai oleh negara tidak berarti negara sendiri menjadi pengusaha atau usahawan. "Dikuasai" mengandung arti bahwa kekuasaan negara terdapat pada membuat peraturan guna melancarkan perekonomian, peraturan yang melarang penghisapan orang yang lemah oleh orang yang bermodal.

3. Pasal 33 UUD 1945, ayat (3) menyatakan bahwa "Bumi, air dan kekayaan alam yang terkandung di dalamnya digunakan untuk sebesarbesar kemakmuran rakyat". Hal ini menegaskan bahwa posisi rakyat yang substansial (utama). Dengan demikian, demokrasi ekonomi memperoleh justifikasinya, yaitu kepentingan masyarakat lebih utama dari kepentingan orang-seorang, artinya mengutamakan kebersamaan (mutualisme), bukan berdasar individualisme. Pengutamaan kepentingan masyarakat ini tidak mengabaikan hak-hak individu secara semena-mena. Dalam paham demokrasi ekonomi, maka rakyat secara bersama memiliki kedaulatan ekonomi. Ekonomi rakyat (grassroots economy) memegang peran dominan dan menjadi tumpuan ekonomi nasional.

4. Pasal 33 UUD 1945 ayat (2), menyatakan bahwa "perekonomian Nasional diselenggarakan berdasar atas demokrasi ekonomi dengan prinsip kebersamaan, efisiensi berkeadilan, berkelanjutan, berwawasan lingkungan, kemandirian, serta dengan menjaga keseimbangan kemajuan dan kesatuan ekonomi nasional. Adanya perkataan "efisiensi berkeadilan" telah merubah keseluruhan niat terselubung untuk memasukkan pandangan neoliberalisme ekonomi (yang membuka jalan ke arah kapitalisme dan imperialisme baru) ke dalam pasar. Maka kepentingan orang seorang yang diwakilinya dirubah menjadi sosial preference. Mengapa demikian, karena perkataan "efisiensi" dalam perekonomian berorientasi pada maximum gain (dalam badan usaha ekonomi) dan maximum satisfaction (dalam transaksi ekonomi orang seorang). Maksudnya paham ekonomi neoklasikal sebagai wujud dari liberalisme ekonomi yang beroperasi melalui pasar bebas (laissez faire). Pasar bebas membuka jalan untuk daulat pasar menggusur daulat rakyat, pasar bebas akan "mengusur orang miskin bukan menggusur kemiskinan".

C. Arti dan makna sila pancasila dalam kehidupan ekonomi

1. Ketuhanan yang Maha Esa.

Sila pertama ini menekankan pada pentingnya keyakinan kepada Tuhan yang Maha Esa sebagai pencipta seluruh makhluk termasuk bumi beserta segala isinya. Oleh karena itu, sudah menjadi tugas dan kewajiban kita untuk menjaga, memelihara, dan memanfaatkan bumi beserta segala isinya sesuai kebutuhan sebagai wujud ibadah demi kelangsungan dan keseimbangan hidup manusia; Dalam kehidupan ekonomi, sila Ketuhanan Yang Maha Esa menjadi dasar akan pentingnya spirit atau keyakinan yang menekankan pada etika dan moral bangsa dalam perekonomian. Dengan kata lain, perekonomian harus memiliki landasan etis dan pertanggungjawaban kepada sang Khalik. Karena itu, ekonomi Pancasila digagas dan dibangun berdasarkan 
pertimbangan moral dan etika religious, seperti rasa syukur, rasa memiliki, dan sifat jujur.

2. Kemanusian yang Adil dan Beradab

Sila kedua ini menekankan bahwa dalam kehidupan bermasyarakat, manusia sebagai makhluk yang berbudaya dan beradab harus saling menghargai dan bersikap adil, baik dalam hubungannya dengan Tuhan yang Maha Esa, orang lain, maupun lingkungan alam sekitar. Dengan demikian, setiap orang dapat bertanggung jawab dalam menjaga kelestarian lingkungan, dan berusaha untuk tidak menimbulkan kerusakan yang dapat berdampak negatif bagi orang lain. Sila kedua ini menjadi dasar lahirnya rasa saling menghormati, kasih sayang dan kepedulian sosial.

3. Persatuan Indonesia

Sila ketiga ini menekankan pada pentingnya persatuan yang dilatarbelakangi oleh rasa nasionalisme untuk mewujudkan kehidupan yang makmur dan harmonis. Untuk itu, maka pengelolaan sumber daya alam strategis harus dilakukan dengan memanfaatkan potensi modal dalam negeri. Selain hasilnya dapat didistribusikan secara adil dan merata, dampak yang ditimbulkan dari aktifitas pengelolaan sumber daya alam terhadap lingkungan juga dapat di minimalisir. Sila ketiga ini menjadi dasar lahirnya rasa kebersamaan dan cinta tanah air.

Dalam kehidupan ekonomi, kebijakan ekonomi yang didasarkan pada Persatuan Indonesia bertujuan untuk mempersatukan bangsa. Apabila kemudian justru memudarkan semangat persatuan bangsa maka kebijakan tersebut pastilah bukan bercorak atau bercirikan ekonomi Pancasila. Dalam hal ini, usaha bersama menjadi kuncinya. Produksi dan distribusi yang dikerjakan melalui mekanisme usaha bersama dalam peningkatan ekonomi memperkecil kesenjangan yang berpotensi memecah belah bangsa. Dalam konteks ini, maka kemudian negara mengambil peran strategis untuk melakukan proses distribusi akses sumber daya ke wilayah-wilayah negara sesuai dengan prinsip keadilan dan pemerataan.
4. Kerakyatan yang Dipimpin Oleh Hikmat Kebijaksanaan Dalam Permusyarawatan Perwakilan

Sila keempat menekankan pentingnya rasio atau akal sehat untuk tidak memaksakan kehendak dalam setiap pengambilan keputusan, termasuk pula dalam aktifitas ekonomi yang terkait dengan pengelolaan sumber daya alam dan lingkungan. Terkait dengan itu, maka prinsip yang harus dikedepankan yaitu bahwa sumber daya alam dan lingkungan menyangkut hajat hidup orang banyak, sehingga setiap orang perlu mengawasi, dan mendapatkan akses yang adil untuk memanfaatkan sumber daya alam dan lingkungan secara bijaksana. Sila keempat ini menjadi dasar lahirnya nilai gotong royong, tanggung jawab, dan tidak memaksakan kehendak.

5. Keadilan Sosial Bagi Seluruh Rakyat Indonesia

Sila kelima ini menekankan pada pentingnya mewujudkan keadilan dalam kehidupan bermasyarakat yang tidak hanya dirasakan oleh generasi sekarang tetapi juga oleh generasi yang akan datang. Salah satu cirinya adalah tercapainya kemakmuran rakyat secara menyeluruh dan bukan kemakmuran orang seorang. Untuk itu, maka sumber daya alam dan lingkungan perlu dikelola secara maksimal dengan mengedepankan prinsip keberlanjutan sehingga kelestarian sumber daya alam dan lingkungan juga dapat dinikmati oleh generasi yang akan datang. Sila kelima ini menjadi dasar lahirnya rasa keadilan, kekeluargaan, dan kemandirian.

D. Hasil Uji Coba

Setelah prototype pembelajaran ekonomi berjatidiri bangsa yang terdiri dari Silabus, RPP dan Materi ajar dirumuskan, maka selanjutnya dilakukan uji coba dalam proses pembelajaran mata kuliah pengantar ilmu ekonomi pada mahasiswa pendidikan ekonomi UNM angkatan 2017. Adapun hasil uji coba produk dapat disimpulkan bahwamateri pembelajaran ekonomi berjatidiri bangsa sangat efektif di terapkan dalam proses pembelajaran. Hal ini ditunjukkan oleh perolehan nilai rata rata hasil belajar sebesar $96.24 \%$ dengan kriteri sangat baik. 


\section{SIMPULAN}

Desain pengembangan materi ekonomi berjati diri bangsa merupakan salah satu inovasi dalam pembelajaran ekonomi. Hal ini merupakan salah satu upaya untuk mengatasi kekurangan literatur pembelajaran ekonomi yang berjatidiri bangsa walaupun penggunaannya sebagai suplemen pembelajaran. Dengan demikian, dapat terwujud sumber daya manusia sebagai generasi penerus, yang mampu bersikap

\section{DAFTAR RUJUKAN}

Degeng, I. N. S. 2013. Ilmu Pembelajaran, Klasifikasi Variabel Untuk Pengembangan Teori dan Penelitian. Bandung: Kalam Hidup.

Dick, W., \& Carey, L. 2001. The Sistematic Design of Instruction: Third Edition. USA: Harper Collins Publishers.

Djauhari. 2007. Demokrasi Ekonomi Pasca Amandemen pasal 33 UUD 1945 sebagai bentuk kompromi. Jurnal Hukum Online, XVII (1):37-40. http://cyber.unissula.ac.id/. Diakses 18 November 2014.

Mubyarto. 2003. Ekonomi Pancasila, Gagasan dan Kemungkinan. Jakarta: LP3S

Nugroho, I. 2010. Nilai-Nilai Pancasila Sebagai Falsafah Pandangan Hidup Bangsa Untuk Peningkatan Kualitas Sumber Daya Manusia Dan Pembangunan Lingkungan Hidup. Jurnal Konstitusi, Volume III, No. 2, November 2010 dan berperilaku tidak hanya untuk tujuan saat ini atau bersifat jangka pendek, tetapi berorientasi pada tujuan jangka panjang. Secara umum dari hasil uji coba pembelajaran, maka dapat disimpulkan bahwa materi pembelajaran ekonomi berjatidiri bangsa pada mata kuliah pengantar ilmu ekonomi sangat efektif diterapkan. Hal ini berdasarkan hasil uji coba dengan kriteria sangat baik

Poespowardojo, S. \& Hardjatno, N. J. M. T. 2010. Pancasila Sebagai Dasar Negara dan Pandangan Hidup Bangsa. Pokja Ideologi. Lemhannas, Jakarta.

Rusliana, E. 2013. Dasar Perekonomian Indonesia Dalam Penyimpangan Mandat Konstitusi UUD Negara tahun 1945. Yogyakarta: Total Media.

Suyono, G. 2012. Analisis Kelayakan Buku Ajar Ekonomi Dari Perspektif Ekonomi Pancasila, Disertasi. Malang:Pascasarjana Universitas Negeri Malang.

Swasono, S. E. 2003. Kompetensi dan Integrasi Sarjana Ekonomi: http://www.ekonomirakyat.org/

Swasono, S. E. 2010. Indonesia dan doktrin kesejahteraan social. Jakarta: Prakarsa.

Wahjoedi. 2015. Pendidikan Ekonomi Berkarakter Nilai-Nilai Pancasila. Malang: Universitas Negeri Malang. 